\title{
ANALYSES OF THERMAL ANNEALING INFLUENCE ON WWER 440 REACTOR PRESSURE VESSEL INTERNALS MATERIALS
}

\author{
${ }^{1}$ Petra PETELOVÁ, ${ }^{1} I$ vana ELIÁŠOVÁ, ${ }^{1}$ Radim KOPŘIVA, ${ }^{1}$ Ondřej BURŠíK, ${ }^{1}$ Dana TONAROVÁ, \\ ${ }^{2}$ Aleš MATERNA
}

\author{
${ }^{1} U$ ÚJ Řež, a. s., Husinec, Czech Republic, EU, petra.petelova@ujv.cz, ivana.eliasova@ujv.cz, \\ ondrej.bursik@ujv.cz radim.kopriva@ujv.cz, dana.tonarova@ujv.cz \\ ${ }^{2}$ Czech Technical University in Prague, Faculty of Nuclear Sciences and Physical Engineering, Prague, \\ Czech Republic, EU, ales.materna@fifi.cz
}

https://doi.org/10.37904/metal.2019.860

\begin{abstract}
Thermal annealing is a proven material treatment method applicable to WWER type reactor pressure vessels with the aim of prolonging their operational lifetime. However, reactor pressure vessel internals of nuclear power plants are exposed to more severe operating conditions (high pressure and temperatures, higher neutron flux, corrosion environment), which cause gradual degradation of their mechanical properties. Thermal annealing can be one of the possible solutions to re-establish initial mechanical properties of reactor pressure vessel internals materials and thus can contribute to long term operation of nuclear power plants. This paper presents results of mechanical properties evaluation (especially hardness) of non-annealed and annealed state of material of WWER 440 - type reactor internals in initial un-irradiated conditions. Within the project an extensive program of experimental activities realized on un-irradiated materials in initial, work hardened, and annealed state was performed to create basis for further analyses on irradiated structural materials. As an integral part of experimental activities microstructural analyses were also incorporated to study of structural changes of non-annealed and annealed material. This paper includes results obtained within the project TH02020565 "Assurance of Safe and Long-Term Operation of Nuclear Pressure Vessel Internals" which is realized by ÚJV Řež, a. s. in cooperation with Czech Technical University in Prague, FNSPE, in the period from 2017 to 2020 with the support of Technology Agency of the Czech Republic.
\end{abstract}

Keywords: Thermal annealing, mechanical properties, WWER 440 type reactor internals

\section{INTRODUCTION}

Reactor pressure vessels are the most important components of any nuclear power plants (NPP's) as they contain practically full inventory of radioactive materials, their failure cannot be neutralized by any measure and their lifetime determine economical lifetime of NPP as they are practically non-replaceable [1]. The thermal annealing is one of the techniques used to reverse the ageing process which causes NPP pressure vessels to lose some of their ductility over time [2]. A similar process, which would be focused on reactor internals, has not been realized yet. The internal parts are exposed to severe conditions during operation including high neutron flux and aggressive chemical environment of the coolant [3]. ÚJV Řež, a. s., Mechanical Testing Department is realizing a research program between years 2017 and 2020. The aim of this research is design, development and certification of a standard procedure for restoring initial properties of WWER 440 - type reactor internals by the thermal annealing method. Successful solution of this problem will contribute to longterm operational life of NPP's and could eventually lower radioactive waste production.

\subsection{Project overview}

Main task was to design several thermal annealing regimes and to demonstrate their application to unirradiated and irradiated materials. Mechanical properties evaluation of unirradiated specimens before and after annealing treatment (hardness tests, microstructural analysis) is necessary. In the next part, mechanical 
properties evaluation of irradiated specimens after annealing treatment (hardness tests, static fracture toughness of miniaturized compact test, corrosion mechanical testing) will follow. The final task of this project TH02020565 "Assurance of Safe and Long-Term Operation of Nuclear Pressure Vessel Internals" will be certification of thermal annealing process for reactor pressure vessel (RPV) internals.

\section{EXPERIMENTAL}

\subsection{Material}

The WWER - 440 type reactor internals are made from corrosion resistant titanium stabilized austenitic stainless steel 08Kh18N10T. Corrosion resistant 08Kh18N10T austenitic stainless steel (ASTM equivalent AISI 321) is chromium - nickel steel stabilized with titanium to prevent carbide precipitation and designed to work within the temperature range, where carbide precipitation can develop. Steel stabilized at temperatures between $950{ }^{\circ} \mathrm{C}$ and $1010{ }^{\circ} \mathrm{C}$ resists scaling and vibration fatigue. It is used for production of various components of the pressure water reactor WWER 440 [4].

For the experimental part of project, two different batches of the austenitic stainless steel 08Kh18N10T were tested. The chemical composition of the first analyzed batch (number 278075) is shown in Table 1. The chemical composition of the second batch (steam generator collector from NPP Greifswald) is shown in

Table 2.

Table 1 Chemical composition of the 08Kh18N10T austenitic stainless steel, number 278075 (wt\%, resp. ppm for $\mathrm{N}$ and $\mathrm{H}$ only) all remaining elements $.10^{-2}$

\begin{tabular}{|ccccccccccccccccc|}
\hline $\mathrm{C}$ & $\mathrm{Mn}$ & $\mathrm{Si}$ & $\mathrm{P}$ & $\mathrm{S}$ & $\mathrm{Cr}$ & $\mathrm{Ni}$ & $\mathrm{Cu}$ & $\mathrm{Mo}$ & $\mathrm{Al}$ & $\mathrm{Ti}$ & $\mathrm{V}$ & $\mathrm{Nb}$ & $\mathrm{N}$ & $\mathrm{W}$ & $\mathrm{Co}$ & $\mathrm{H}$ \\
0.5 & 166 & 52 & 3.1 & 0.5 & 1750 & 1010 & 12 & 9 & 0.58 & 35 & 7 & 0.24 & 130 & 3 & 4 & 1.4 \\
\hline
\end{tabular}

Table 2 Chemical composition of the 08Kh18N10T austenitic stainless steel (steam generator collector from NPP Greifswald), (wt\%), all elements .10-2

\begin{tabular}{|ccccccccccc|}
\hline $\mathrm{C}$ & $\mathrm{Si}$ & $\mathrm{Mn}$ & $\mathrm{Cr}$ & $\mathrm{Ni}$ & $\mathrm{Cu}$ & $\mathrm{Mo}$ & $\mathrm{Ti}$ & $\mathrm{Al}$ & $\mathrm{P}$ & $\mathrm{V}$ \\
10.2 & 52 & 144.6 & 1808 & 979 & 4.8 & 2.3 & 6.1 & 10.9 & 2.3 & 1.3 \\
\hline
\end{tabular}

\subsection{Testing specimens}

The specimens for testing of mechanical properties were cut from the unirradiated blocks of material (both batches of austenitic stainless steel 08Kh18N10T) Figure 1. These unirradiated specimens were used for the evaluation of mechanical properties (especially hardness) before and after thermal annealing. Test specimens prepared from first batch of austenitic stainless steel 08Kh18N10T were made with dimensions of $12 \mathrm{~mm} \times 12$ $\mathrm{mm} \times 60 \mathrm{~mm}$ (Figure 2). Test specimens prepared from the second batch were made with dimensions $15 \mathrm{~mm}$ x $15 \mathrm{~mm} \times 17 \mathrm{~mm}$ (Figure 3).

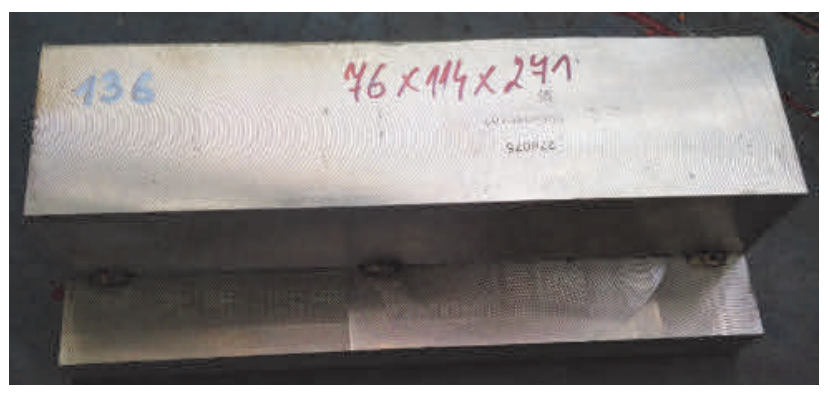

Figure 1 Unirradiated block of material of austenitic stainless steel $08 \mathrm{Kh} 18 \mathrm{~N} 10 \mathrm{~T}$, first batch 


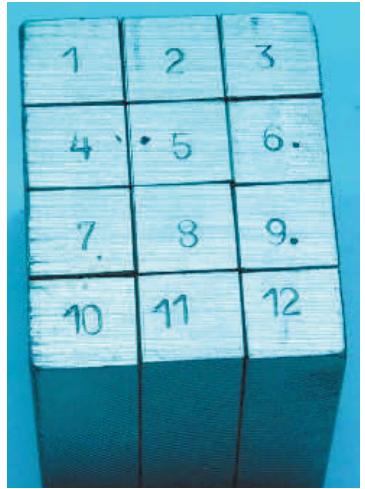

Figure 2 Unirradiated test specimens $12 \mathrm{~mm} \times 12 \mathrm{~mm} \times 60 \mathrm{~mm}$, first batch of $08 \mathrm{Kh} 18 \mathrm{~N} 10 \mathrm{~T}$

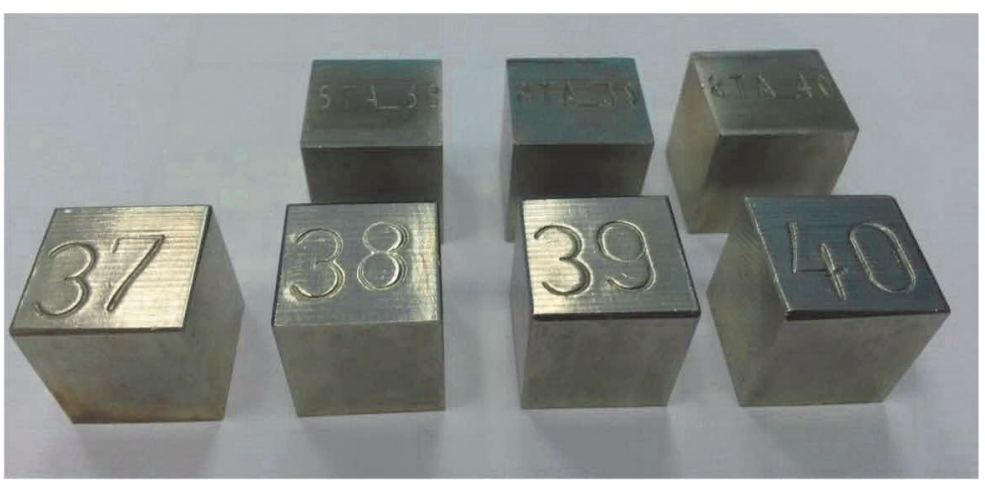

Figure 3 Unirradiated test specimens, $15 \mathrm{~mm} \times 15 \mathrm{~mm} \times 17 \mathrm{~mm}$, second batch - steam generator collector from NPP Greifswald

\subsection{Annealing furnace}

Laboratory of Mechanical Testing Department is equipped with furnace (Figure 4), which is used for thermal annealing of metallic materials in protective atmosphere at high temperature. Temperature is controlled with three independent thermocouples and regulated by temperature regulator Clare 4.0. The moving mechanisms are driven by compressed air. Outer surfaces are cooled by water as a coolant with forced circulation and water - air passive heat exchanger. Annealing experiments are controlled by PC which is also used for data recording. Before the annealing process starts, the furnace inner environment is cleaned using a vacuum pump and a repetitive flushing of the furnace chamber and the sample with an inert gas. Annealing experiments could be controlled using integrated GSM module.
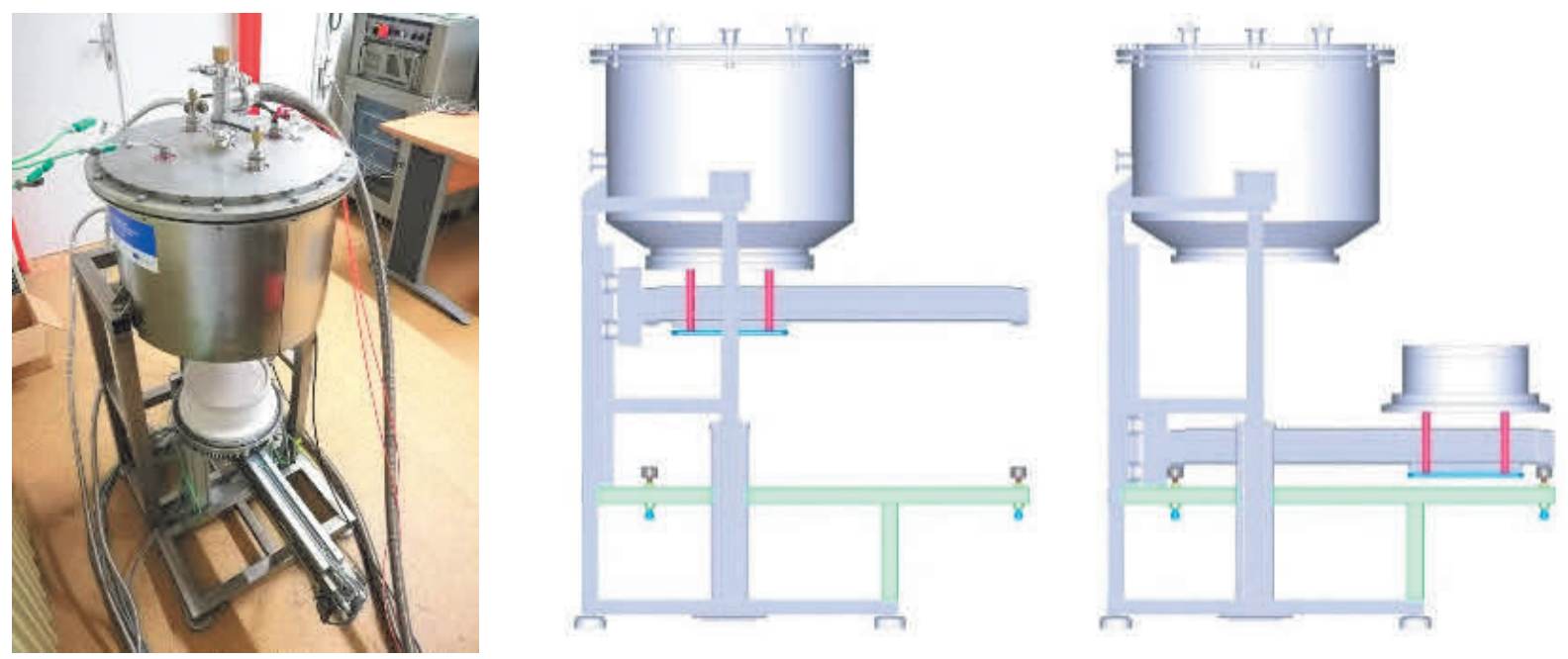

Figure 4 Annealing furnace

\subsection{Annealing regimes}

Several thermal annealing regimes were selected for unirradiated specimens: $450{ }^{\circ} \mathrm{C}, 500{ }^{\circ} \mathrm{C}, 550^{\circ} \mathrm{C}, 600^{\circ} \mathrm{C}$, $700{ }^{\circ} \mathrm{C}, 800{ }^{\circ} \mathrm{C}, 900{ }^{\circ} \mathrm{C}$. Other process parameters were as follows: heating rate $-10{ }^{\circ} \mathrm{C} / \mathrm{min}$, holding time -6 hours, cooling - inside the furnace to room temperature, experiment duration - approx. 24 hours, environment - air (2l per minute flow), specimen load - either one or several pieces, end of experiment $-50^{\circ} \mathrm{C}$ or lower temperature. 


\section{EXPERIMENTAL RESULTS AND DISCUSSION}

\subsection{Hardness tests results}

The hardness test is a mechanical test for material properties which are used in engineering design, analysis of structures, and materials development. The principal purpose of the hardness test is to determine the suitability of a material for a given application, or the treatment to which the material has been subjected. For this project, the Vickers hardness test method HV5 was selected (ČSN EN ISO 6507-1 Metallic materials Vickers hardness test - Part 1

The hardness test measurements were made on Zwick/Roell Indentec ZVH 30. This device is located in semihot cell in the laboratory of Mechanical Testing Department and allows the hardness measurements of unirradiated and irradiated materials. The hardness measuring results of first batch austenitic stainless steel 08Kh18N10T before and after thermal annealing are shown in Table 3. The hardness measuring results of second batch austenitic stainless steel 08Kh18N10T before and after thermal annealing are shown in Table 4.

Table 3 The hardness test results of first batch austenitic stainless steel 08Kh18N10T

\begin{tabular}{|ccccccccc|}
\hline & \multicolumn{8}{c|}{ Thermal annealing temperature } \\
State & Initial & $\mathbf{4 5 0}{ }^{\circ} \mathbf{C}$ & $\mathbf{5 0 0}{ }^{\circ} \mathbf{C}$ & $\mathbf{5 5 0}{ }^{\circ} \mathbf{C}$ & $\mathbf{6 0 0}{ }^{\circ} \mathbf{C}$ & $\mathbf{7 0 0}^{\circ} \mathbf{C}$ & $\mathbf{8 0 0}^{\circ} \mathbf{C}$ & $\mathbf{9 0 0}{ }^{\circ} \mathbf{C}$ \\
Hardness HV5 & 181 & 164 & 164 & 171 & 161 & 178 & 163 & 160 \\
\hline
\end{tabular}

Table 4 The hardness test results of second batch austenitic stainless steel 08Kh18N10T

\begin{tabular}{|ccccccccc|}
\hline & \multicolumn{7}{c|}{ Thermal annealing temperature } \\
State & Initial & $\mathbf{4 5 0}{ }^{\circ} \mathbf{C}$ & $\mathbf{5 0 0}{ }^{\circ} \mathbf{C}$ & $\mathbf{5 5 0}{ }^{\circ} \mathbf{C}$ & $\mathbf{6 0 0}{ }^{\circ} \mathbf{C}$ & $\mathbf{7 0 0}^{\circ} \mathbf{C}$ & $\mathbf{8 0 0}^{\circ} \mathbf{C}$ & $\mathbf{9 0 0}{ }^{\circ} \mathbf{C}$ \\
Hardness HV5 & 187 & 190 & 181 & 174 & 170 & 173 & 160 & 146 \\
\hline
\end{tabular}

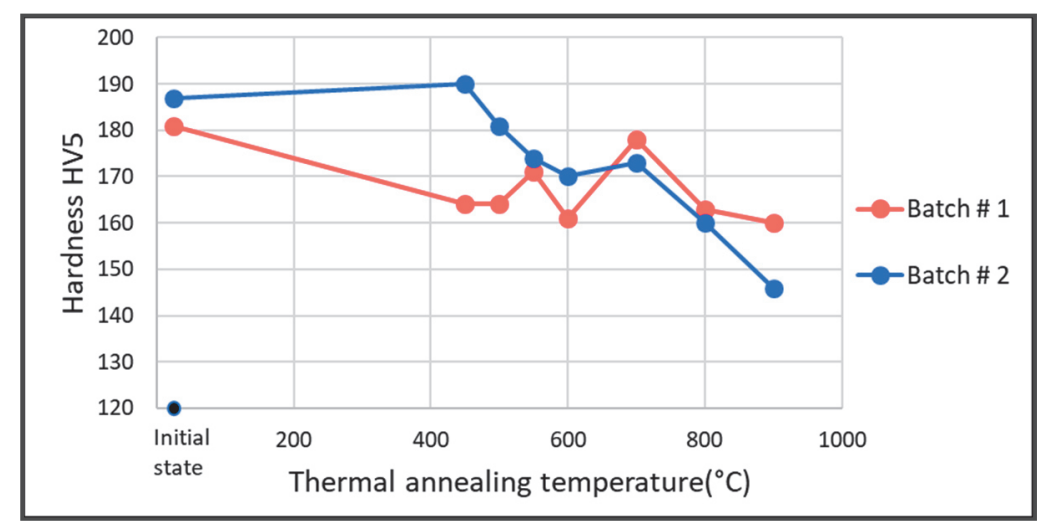

Figure 5 Comparison of hardness measurement results (HV5) of both experimental batches of austenitic stainless steel 08Kh18N10T

Based on results of all experimental activities, the optimal annealing temperature is in the range of 450 $650^{\circ} \mathrm{C}$. This temperature range demonstrated positive material response to the thermal annealing. On the other side, thermal annealing at temperature $700^{\circ} \mathrm{C}$ showed only small decrease of hardness, probably due to secondary hardness effect, see Figure 5.

All test specimens are composed of austenitic grains of different size (Figure 6). Microstructural analysis and grain size measurement showed that the final hardness decreased due to changes of grain sizes - Hall Petch equation (the strength of steel increases when the grain sizes are smaller). Due to thermal annealing process, growth of original grains occurred and new smaller grains formed. 
Further, the sensibility to intercrystalline corrosion of selected samples (initial state, thermal annealing $550{ }^{\circ} \mathrm{C}$, $600^{\circ} \mathrm{C}, 700^{\circ} \mathrm{C}, 800^{\circ} \mathrm{C}$ ) was established. The grain boundaries were formed by carbide inclusions. Specimen in initial state and specimen annealed at $550^{\circ} \mathrm{C}$ did not show any corrosion inclusions on the surface. On the surface of the samples annealed at $600^{\circ} \mathrm{C}$ (Figure $7 \mathrm{~A}$ ) and $700{ }^{\circ} \mathrm{C}$ (Figure $7 \mathrm{~B}$ ), corrosion inclusions $\sim 5 \mu \mathrm{m}$ in depth were found. On the surface of the sample annealed at $800{ }^{\circ} \mathrm{C}$ (Figure $7 \mathrm{C}$ ), corrosion inclusions $\sim 17$ $\mu \mathrm{m}$ in depth were found locally. Around these inclusions, intercrystallite corrosion was observed.
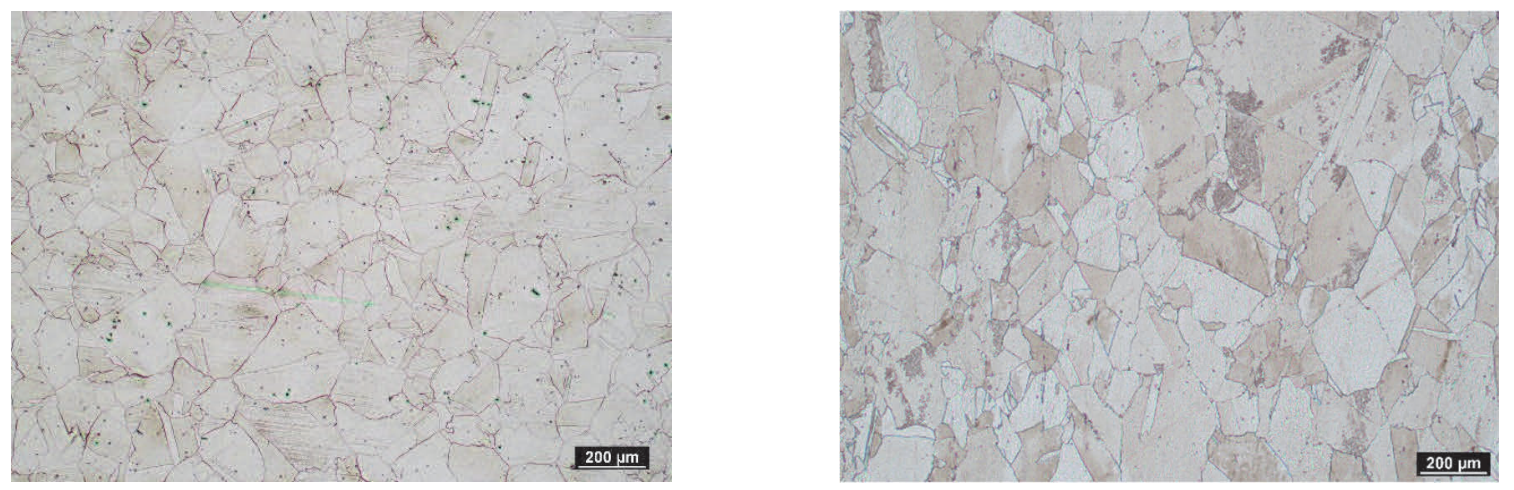

Figure 6 Microstructure of initial state of austenitic stainless steel 08Kh18N10T

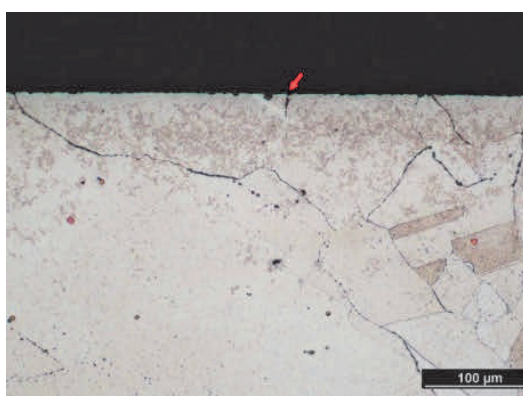

A

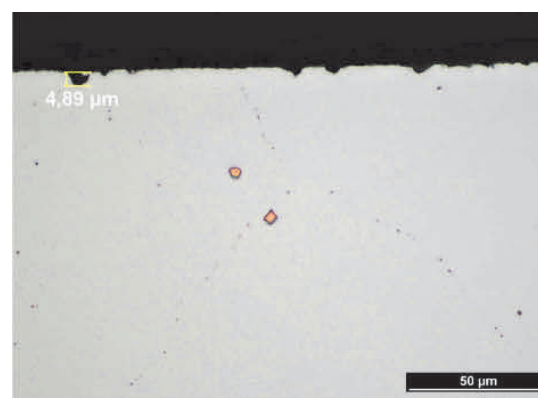

B

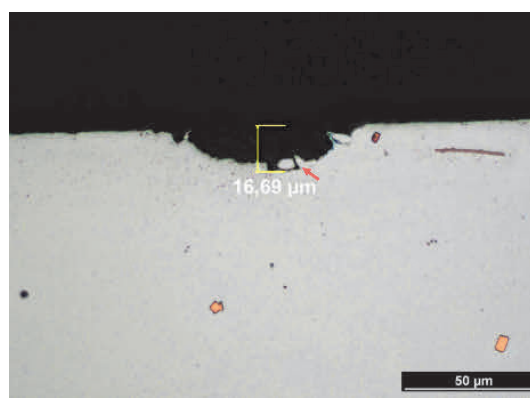

C

Figure 7 Microstructure surface detail of thermal annealed of $08 \mathrm{Kh} 18 \mathrm{NT} 10$ steel $\left(\mathrm{A}-600{ }^{\circ} \mathrm{C}, \mathrm{B}-700{ }^{\circ} \mathrm{C}\right.$, $\mathrm{C}-800^{\circ} \mathrm{C}$ ) after intercrystalline corrosion test (cross - section)

\section{CONCLUSION}

Thermal annealing of unirradiated specimens and following mechanical testing was the first step to establish one annealing regime for its application to irradiated specimens. The results of thermal annealing of unirradiated specimens showed that thermal annealing at higher temperatures above $700{ }^{\circ} \mathrm{C}$ caused the intercrystalline corrosion and also Hall Petch strengthening was observed. Also, the secondary hardness was detected on the specimen annealed at $700{ }^{\circ} \mathrm{C}$. Based on the results of these analyses, the following temperatures for thermal annealing of irradiated materials were selected: $550{ }^{\circ} \mathrm{C}, 600{ }^{\circ} \mathrm{C}$.

The next steps of this project will be fracture toughness tests on miniature CT (unirradiated and irradiated specimens), corrosion mechanical tests of unirradiated and irradiated specimens, thermal annealing of irradiated specimens in selected temperatures regimes $\left(550^{\circ} \mathrm{C}, 600^{\circ} \mathrm{C}\right)$, hardness tests and microstructural analysis of irradiated specimens before and after thermal annealing. The final mechanical and corrosionmechanical testing of irradiated specimens will help to confirm the proper annealing regime for WWER 440 internals. Following certification of the thermal annealing methodology of the internal components is one step in possible restoration of the mechanical properties of highly irradiated materials. That will contribute to the implementation of this methodology into industrial practice. 


\section{ACKNOWLEDGEMENTS}

This paper includes results created within the projects supported by Technology Agency of the Czech Republic: TH02020565 - „Assurance of Safe and Long-Term Operation of Nuclear Reactor Pressure Vessel Internals “.

\section{REFERENCES}

[1] BRUMOVSKY, M. Annealing and Re-Embrittlement of RPV Materials, Join Research Centre - Institute for Energy, Ames report N. 19. 2008. pp. 11-33.

[2] CEPN ISOE Information Sheet No. 12 - September 1997: Occupational exposure and reactor pressure vessel annealing. [online]. ISOE European Technical Centre - CEPN Information Sheet No. 12 (1997) [viewed 2019-0505]. Available from: http://www.isoe-network.net/publications/pub-resources/pub-info-sheet/etc-informationsheets/198-etc-12/file.html

[3] IAEA: Assessment and Management of Ageing of Major Nuclear Power Plant Components Important to Safety: PWR Vessels Internals, 2007 Update. IAEA-TECDOC -1556, 2007, p. 74-108.

[4] NAGEShA, A., VAlSANA, A. M., KANNANA, R., BHANU, S., R. K., NAUERB, V., CHRISTIC, H. - J. and SINGHD, V. Thermomechanical Fatigue Evaluation and Life Prediction of 316L Stainless Steel. International Journal of Fatigue. 2009. vol. 31, p. 636 - 643. 